\title{
WATER CITY ROTTERDAM 2035
}

\author{
NICOLINE LOEPER \& MATTHIAS OTT \\ Urban Nomads Institute, The Netherlands
}

\begin{abstract}
New land was constructed in the North Sea to modernize and extend the Port of Rotterdam: Maasvlakte 2. This new artificial island of 1000 hectares shifts the harbor activities of one of the biggest harbors worldwide further to the west, and enables the reconstruction of the former harbor and the development of new urban areas of the city of Rotterdam. The strategic focus of the urban development plan is to use the transformation to develop a "Clean Tech City" on the water: Water City Rotterdam 2035.

This case study analyses the historical transformation processes of the city of Rotterdam to give insight into the relation of the harbor with the landscape and the city. A comparative study analyses the newly developed strategic design instruments of the four different areas (Merwe-Vier harbors, RijnMaas harbors, Waal-Eem harbors and RDM-Heijplaat) to conclude whether or not these tools are adequate to transform the areas sustainable. The developed design instruments are tested in three different designs to critically reflect on the conclusion.
\end{abstract}

Keywords: Rotterdam, urban design, harbor cities, sustainable transformation of harbor areas, strategic design instruments.

\section{INTRODUCTION}

A permanent transformation, renovation and innovation process is an evident characteristic of dynamic harbor cities.

Could we, as urban designers, profit from these permanent changes and could we be able to direct these transformations into a sustainable development of the entire city? Could we learn from these transformation processes how to design in dynamic circumstances and could we develop new design principles which enable us to react with flexible design solutions instead of static masterplans?

The city of Rotterdam proclaimed the vision of a figurehead Clean-Tech City. In this paper the transformation of the city of Rotterdam is studied carefully to give insight into the current developments and to enable a critical reflection on the planned proposals.

\section{DYNAMIC TRANSFORMATIONS OF ROTTERDAM}

From 2009 until 2014 new land was constructed in the North Sea to modernize and to extend the Port of Rotterdam: Maasvlakte 2. The new international deep-sea terminal which demands a water depth of $25 \mathrm{~m}$ was constructed on Maasvlakte 2. This new artificial island of 1000 hectares shifts the harbor activities of one of the biggest harbors worldwide further to the west and enables the reconstruction of the former harbor and the development of new urban areas of the city of Rotterdam.

This recent transformation process of harbor activities is characteristically for the development of the city of Rotterdam and the whole delta region. Historical maps give clear insight in the interplay between harbor activities, the new shape of landscapes, new waterways and the urban development (Fig. 1).

The urban development and the architecture of Rotterdam has always been forward looking and open minded. The modernistic movement and the rational American city were the ideals of the reconstruction plans of the completely destroyed city center after World War II. Rotterdam designed the first pedestrian zone (Lijnbaan) in Europe, realized the first metro line in the Netherlands. 


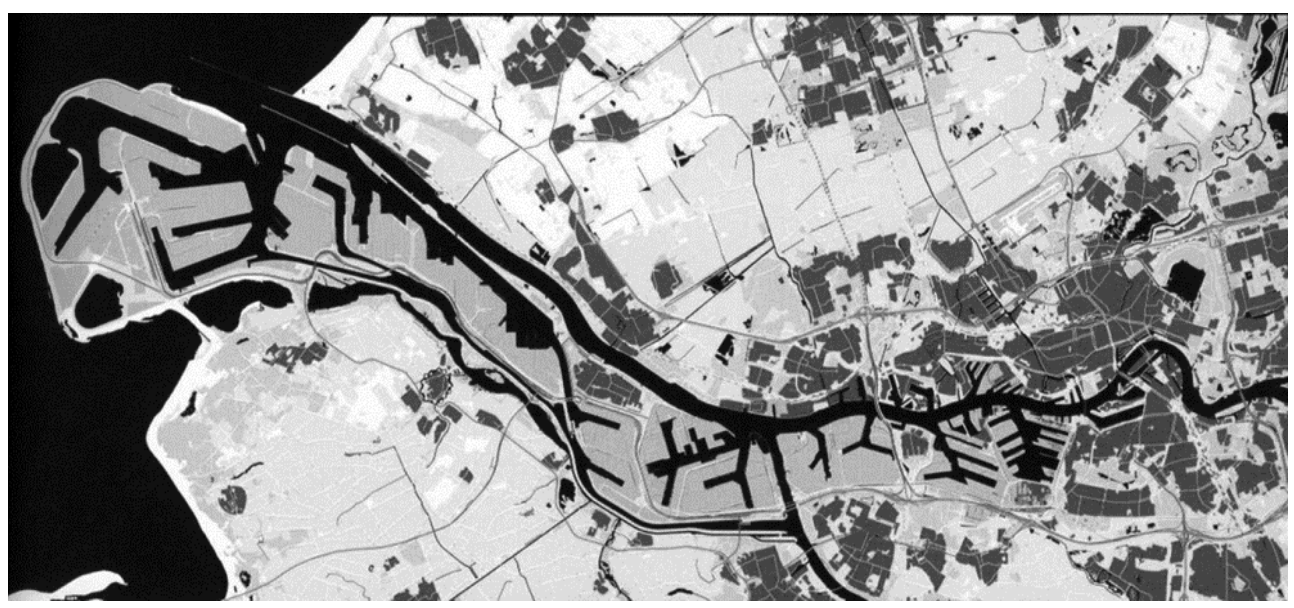

Figure 1: Area of Rotterdam [1].

The big harbor extensions in the sixties were determined by the rules of mass production and mass consumption and results in the construction of Maasvlakte 1. But due to the oil crisis in 1973 and the postulated "limits of growth" by the Club of Rome in 1972 [2] the mindset changes. The quality of the different spatial spaces of the transformation and the renewal replace the quantity of it. Therefore, the harbor, the city and the landscape must be regarded as an integral system. Although the construction of Maasvlakte 2 is driven by economical profits, it is an example of "collateral benefits" [3] which creates a new quality of spaces.

\section{THE CHALLENGE OF THE TRANSFORMATION: \\ A CLEAN TECH CITY ON THE RIVER}

In 2015 the city of Rotterdam presented an urban development plan, "Structuurvisie Stadhavens Rotterdam" [4], about the transformation of 1600 hectares of abandoned harbor areas. This ambitious plan aims to develop the area within the next 20-30 years into a new sustainable Clean Tech City quarter. The design strategy for the 4 new waterfronts provides a temporary and trendsetting start with different design principles. Merwe-Vierhavens becomes an international experimental cluster for innovative energy resources. New prototypes of energy-neutral developments and floating housing are demonstrated to the public in the Rijn-Maashaven. The Waal-Eemhaven will be transformed from a deep-sea container harbor into a shortsea-hub with a maritime technology cluster. Universities, research institutes and creative industry transform the former docklands into a research, design and manufacturing (RDM) lab (Fig. 2).

\subsection{Merwe-Vier harbors}

The area of Merwe-Vier harbors transforms into an international experimental area for innovative power supply and intelligent water management. This is possible due to new floating housing concepts which will be realized by $\mathrm{CO}_{2}$ neutral production processes. The Merwe-Vier harbors are situated on the north bank of the river Maas and profit from the good physical connection to the Technical University of Delft. Scientists, consultants and engineering agencies combine their knowledge and skills on this creative playground. 


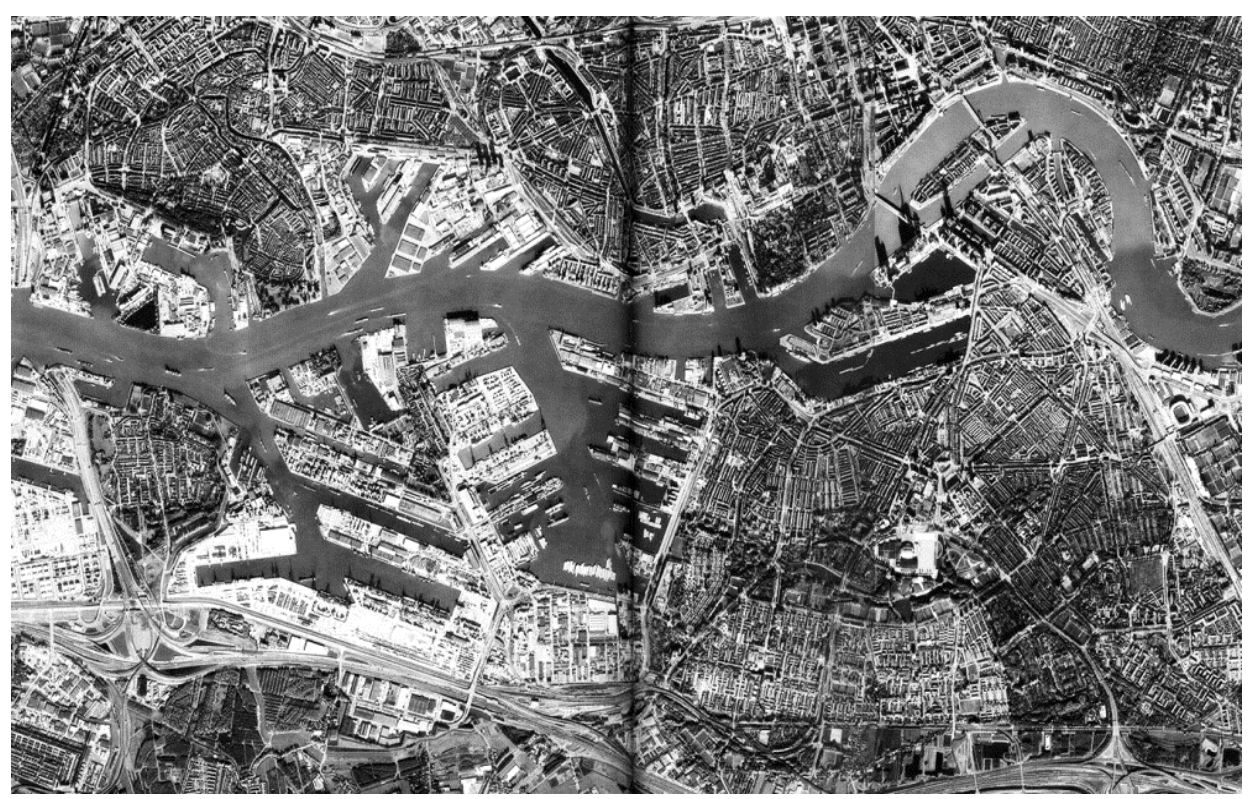

Figure 2: Stadshavens area [5].

As long as the food harbor is still active in Merwe harbor the first step of the transformation is processed by all kinds of creative pioneers like artists, urban agriculturists and entrepreneurs. The authorities invited them to use the abandoned spaces and stores to experiment with new life style concepts. In the next phase these pioneers will live in the newly developed $\mathrm{CO} 2$ neutral floating houses. Partly, they will claim, use and transform the rough and tough spaces of the harbor.

Thus a new city quarter will rise in the long run on the banks of Merwe-Vier harbors. The icons and hotspots of this new sustainable area are the already existing Clean Tech companies: the power plant and the national water center. Together they generate the identity of the new area on the waterfront: prestigious showcases of innovative water management and intelligent energy supply, like, for example, autarkic floating housing concepts to react on the expected rising of the sea level, or systems to filter drink water out of brackish water.

The metamorphosis of Merwe-Vier harbors will also have an effect on the economic and social composition of the inhabitants of the adjacent small cities Delftshaven and Schiedam. The newly constructed Marconistrip (Fig. 3) already offers shopping, work and recreation facilities, which complement the range of goods of the historical city center of Schiedam. The newly built spatial connection of the historical center of Schiedam with Merwe harbor is an important key project to increase the spatial quality of both areas.

The newly designed 4500-6000 apartments, facilities and start-ups should fit with the existing rough atmosphere and the big scale of the harbor.

\subsection{Rijn-Maas harbors}

Rijn-Maas harbors (Fig. 4) are located close to the new Erasmus bridge which connects the Wilhelmina pier with the north part of the City of Rotterdam. This means that Rijn-Maas 


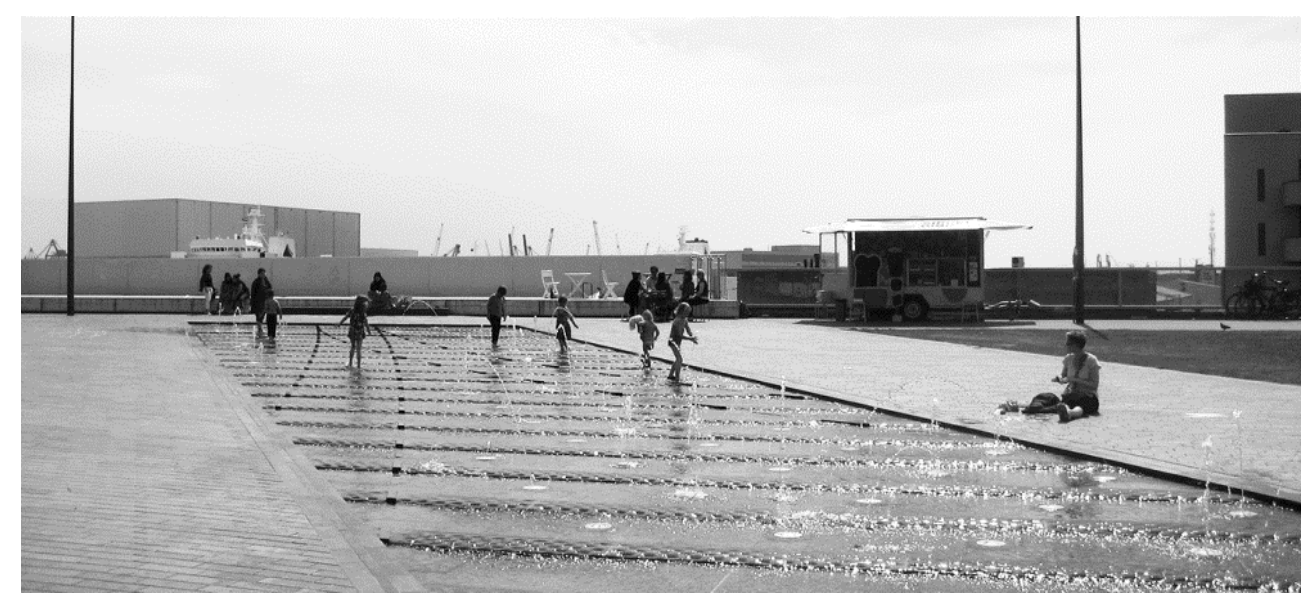

Figure 3: Playground on Marconistrip.

harbor is the closest harbor of the Stadhavens project to the historical city center of Rotterdam. Rijn harbor will be developed as a showcase for prestigious transformation projects of the other harbors. New trends and inventions of low energy housing and floating constructions will be demonstrated here. The already existing floating expo pavilion is the first piece in a row of climate neutral constructions.

An urban life, work and leisure district is planned on and alongside the water of the Rijn harbor. The building density the quays of Rijn harbor should be very high to create a kind of urban arena around the water basin: the arena of Show City. Show City attracts tourists and experts with different events. There will be floating attractions like a floating pool and temporary exhibitions.

The already started redevelopment of Katendrecht neighborhood will profit from the planned luxury apartments alongside the waterfront of the Maas harbor. The new bridge for cyclists and pedestrians connects the business and cultural cluster of the Wilhelmina pier with Katendrecht. Carefully designed public spaces connect the Rijn harbor via the Maas harbor with the Wilhelmina peer.

In 2020 a construction of a Floating City is planned in the Maas harbor. It will consist of energy-producing floating houses.

\subsection{Waal-Eem harbors}

The existing deep-sea container terminals of the Waal-Eem harbors will be shifted to Maasvlakte 2 or will be transformed into a short-sea hub. Waal-Eem harbors will transform into the main transshipment for containers and general cargo.

In the Waal harbor a service cluster for maritime technology and industry is planned on the Maritime Boulevard. A newly designed public space will connect the existing neighborhoods Oud-Charlois, Wielewaal and Pendrecht with the waterfront of the Waal harbor. A new bridge at pier 3 will connect the Zuider park with the green recreation area of Rotterdam South. The inhabitants of the existing neighborhoods will also profit from new jobs on the Maritime Boulevard, restaurants and new facilities. 


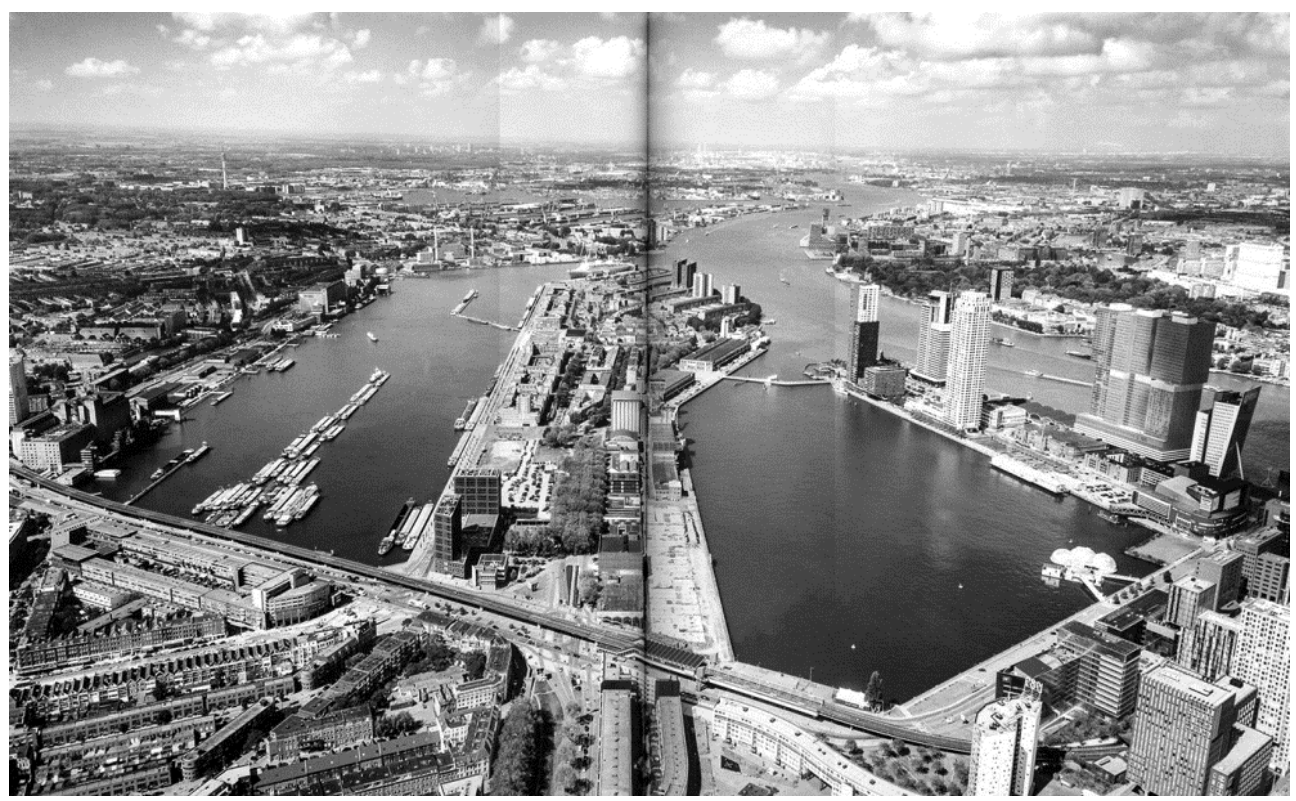

Figure 4: Rijn-Maas harbors [6].

\subsection{RDM-Heijplaat}

RDM-Heijplaat holds a key role in the development of the Stadshavens project. This area consists of the garden city Heijplaat, home of the families of the former workers of the RDM docks. Heijplaat is a green, quiet and isolated village in the harbor landscape.

The green enclave of the former quarantine island belongs also to the area. Nowadays artists have claimed the former hospital buildings on the island which refer to the emigration period. Therefore, the green enclave is preserved as a landscape monument in the harbor.

The huge halls of the RDM contrasts the cozy, small-scaled garden city and the quarantine island. The abandoned construction halls transform into flexible units for education, like the Academy of Architecture and Urban Design, innovative startups and small-scaled enterprises.

The diversity and the dynamic of the harbor stands out on RDM-Hijplaat. Craftsmanship and expertise concerning building, moving and powering are the key words which link together all activities. The former machine hall is transformed into a Innovation Dock which works as a platform to link initiatives of universities, innovative enterprises and creative entrepreneurs. In the lab they develop sustainable concepts about water management, energy production and low energy housing. The boost of the RDM campus pushes on activities and developments of the whole area of Stadhavens.

\section{BEST PRACTICE OF WATER CITY ROTTERDAM 2035}

The Urban Nomads Institute for Urban Design designed the following three examples to give insight in the transformation of the harbor into a sustainable Clean-Tech City. 


\subsection{Housing on the Fenix sheds in the Rijn harbor}

L. Rook designed a concept for a new innovative $\mathrm{CO}_{2}$ neutral housing cocoon on the roof of the existing sheds (Fig. 5). A high-tech shield of an intelligent membrane delivers energy and ventilation for 1000 lofts. The huge sheds are converted into commercial or public functions, like, for example, the Fenix food factory. The futuristic shape of the shell refers to the scale of the existing morphology and is an eye catcher on the public slow traffic route from the Wilhelmina pier to the Maas harbor Show City.

\subsection{A modular system for Merwe-Vier harbors}

C. Lansink developed a modular system for the transformation of the Keilehaven (Fig. 6). Two basic frames allow a horizontal and a vertical extension of the structure. The vertical structure is suitable for different housing units. The horizontal structure offers flexible playgrounds, temporarily usable for different activities like working, playing or recreation. The use of the vertical frame is inextricably combined with the adjacent public space.

\subsection{A new multifunctional green shed in the Merwe-Vier harbors}

J. Veldhuis designed a multifunctional shed to encourage the transformation of the Keilehaven into a dynamic, urban city quarter (Fig. 7). The ecologic roof of the enormous building is responsible for the climate and the water reservoir of the indoor facilities. The roof can be opened and can partially be used as a public park. Due to its shape it is able to connect the existing green and public structures with the new building.

The delivered spaces inside are flexible and can be used for housing (on the first floor) and all other kinds of activities like exhibitions, small rest zones, working units and ateliers.

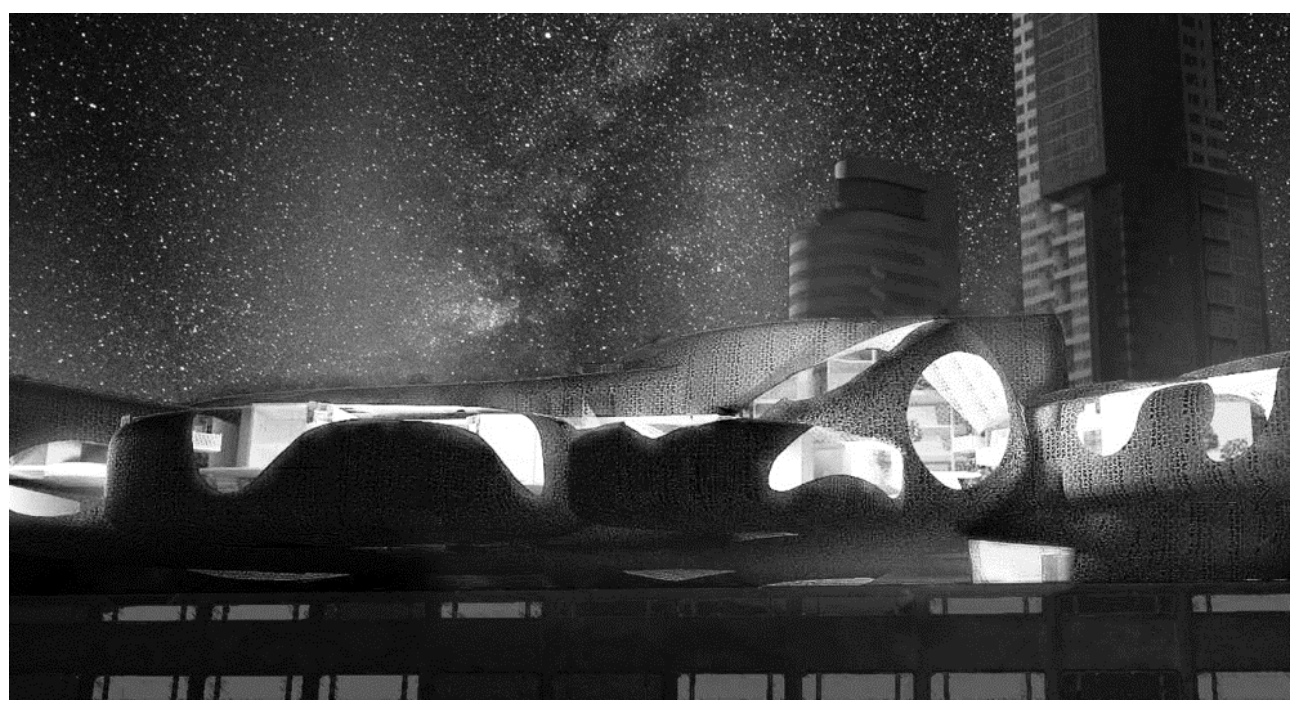

Figure 5: Visualization design of Fenix sheds. 


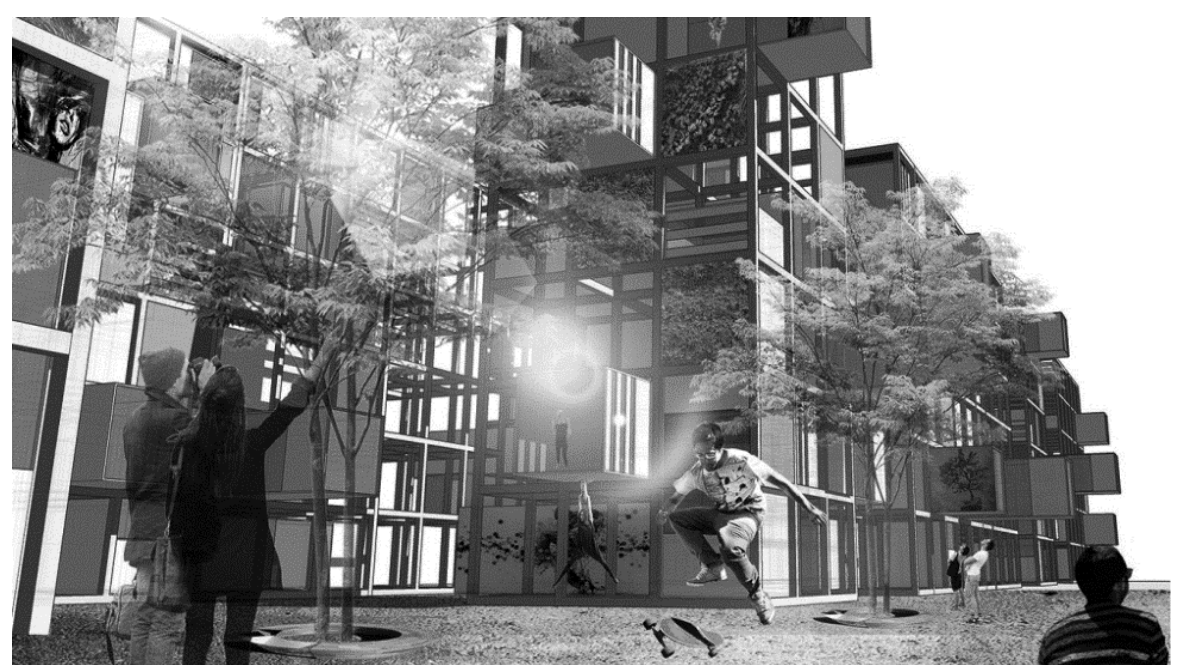

Figure 6: Visualization design of the Keilehaven.

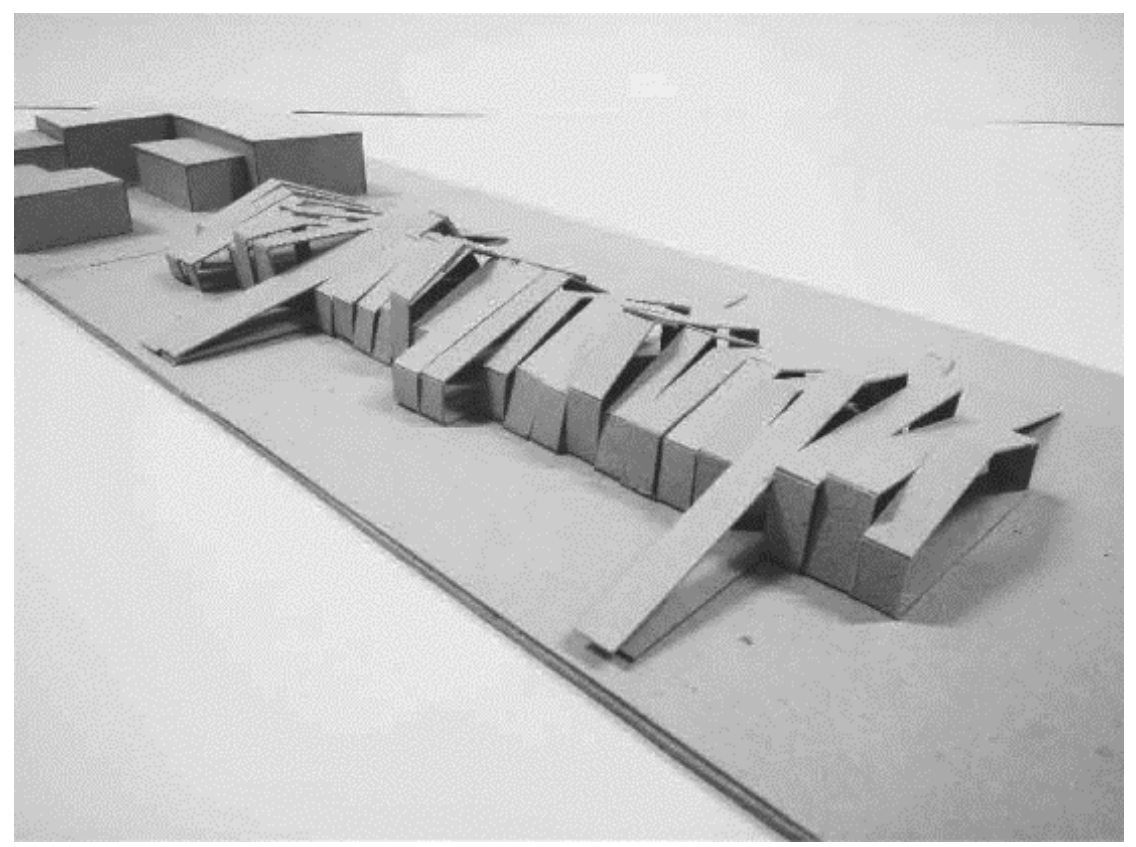

Figure 7: Sketch model of hall.

\section{CONCLUSION}

Although the proclaimed transformation of the abandoned harbors into a Claen Tech City is very ambitions and the transformation process has just started, the urban development plan "Structuurvisie Stadhavens Rotterdam" provides clear design tools and urban development 
guidelines for the 4 different harbors. The strategic urban design plan offers the possibility to anticipate and to respond to unforeseen developments adequately. The chosen design instruments are capable of flexible design and strengthen the existing spatial qualities of the 4 harbor areas in a sustainable way.

\section{REFERENCES}

[1] Steenhuis, M. (ed.), De Haven van Rotterdam, nai010 uitgevers: Rotterdam, p. 29, 2015.

[2] Meadows, D.H., Meadows, D.L., Randers, J. \& Behrens Ill, W.W., The Limits to Growth, Universe Books: New York, 1972.

[3] Geuze, A., Trots, troost en mededogen. In: Steenhuis, M. (ed.), De Haven van Rotterdam, nai010 uitgevers: Rotterdam, p. 194, 2015.

[4] Projectenbureau Stadshavens Rotterdam, Stadshavens Rotterdam 1600 ha Uitvoeringsprogramma 2007-2015, Projectenbureau Stadshavens Rotterdam: Rotterdam, 2008.

[5] Foto Linders, J. \& Swart, S. In: Steenhuis, M. (ed.), De Haven van Rotterdam, nai010 uitgevers: Rotterdam, pp. 238-239, 2015.

[6] Foto Linders, J. \& Swart, S. In: Steenhuis, M. (ed.), De Haven van Rotterdam, nai010 uitgevers: Rotterdam, pp. 82-83, 2015. 